\title{
Simone Weil: o sofrimento como pathos da Filosofia
}

\author{
Simone Weil: Suffering as Pathos of Philosophy
}

BORTOLO VALLE

\section{Resumo}

O presente trabalho toma como objeto de investigação o pensamento de Simone Weil. A filósofa francesa, deixando de lado um imperativo acadêmico, típico da filosofia do século XIX, reclama para si o assombro, o espanto, aquilo que no início, ou seja, nos primórdios da filosofia grega, possibilitou a emergência do filosofar. A marca de seu pensamento é evidenciada mais pela emoção do que pelo exercício racional. Assim, procuramos apresentar, neste estudo, a maneira como o sofrimento, enquanto pathos, constitui a fonte do pensamento da autora, capaz de captar a essência do homem. $O$ breve itinerário destaca, a princípio, utilizando a reflexão de Heidegger, a noção de pathos e percorre a partir daí, a particularidade do sofrimento destacando a noção violência e de força para chegar, finalmente, a realidade do malheur como elemento mais original no entendimento daquilo que é reservado à Filosofia como instância que pode compreender a condição humana.

Palavras-chave: Simone Weil. Pathos. Sofrimento. Violência. Malheur.

\section{Abstract}

This article takes as investigation object the thought of Simone Weil. Leaving aside an academical imperative typical of the nineteenth-century philosophy, the French philosopher claims for herself the astonishment, the amazement, that which at the beginning, since the dawn of Greek philosophy, enabled the philosophizing emergence. Her thought traces are emphasized more by emotion rather than by rational exercise. Therefore, the present paper seeks to set forth how suffering, consisted as pathos, constitutes the source of the author's thought, capable of capturing the man's essence. The brief itinerary, highlights at first, using Heidegger's reflection, the notion of phatos, following from this point on, the particularity trace of suffering emphasizing the notion of violence, of strength

\footnotetext{
a Pontifícia Universidade Católica do Paraná (PUCPR), Curitiba, PR, Brasil; Centro Universitário Curitiba (UNICURITIBA), Curitiba, PR, Brasil; Faculdade Vicentina (FAVI), Curitiba, PR, Brasil. Doutor em Comunicação e Semiótica, e-mail: bortolo.valle@pucpr.br
} 
to finally reach the malheur actuality as most original feature of understanding what is reserved to Philosophy as an element that can comprehend the human condition.

Keywords: Simone Weil. Pathos. Suffering. Violence. Malheur.

Em Simone Weil (1909 - 1943), é imprescindível esclarecer que seu modo de compreender a natureza da filosofia, bem como seu engajamento sociopolítico e sua experiência religiosa são elementos significativamente relacionados — pois se a filosofia é um modus vivendi, toda experiência que venha a ocorrer na vida do homem se torna, necessariamente, um componente filosófico — , uma coisa é assimilar Weil como operária ou mesmo como mística e outra, bem mais complicada, é compreendêla como filósofa.

Simone Weil não buscou elaborar uma filosofia sistemática, escreveu de maneira fragmentária e concebeu seu fazer filosófico como uma obra em progresso, isto é, algo a ser construído paulatinamente. Ademais, ela lia os autores com os quais se deparava de modo bastante livre, o que se evidencia, por exemplo, na maneira como relaciona, por vezes, conceitos da teologia cristã com a filosofia grega de matriz platônica (MARTINS, 2013, p. 73).

Nossa incursão sobre o modus vivendi filosófico weiliano e, consequentemente sobre o pathos do sofrimento, é um exercício livre uma vez que não dispomos, por exemplo, de arcabouço conceitual assegurado pela própria autora para examinar em que consiste o termo pathos e como utilizá-lo na abordagem do tema sofrimento. O termo aparece nessa única e breve ocasião: "Sofrimento, ensinamento e transformação. [...] Pathos significa ao mesmo tempo sofrimento [...] e modificação" (PG, p. 86).

Dado que o nosso intento é tratar o sofrimento não como um conceito que emerge e se desenvolve de modo meramente abstrato na trama das obras de Weil, mas como algo de natureza eminentemente afetiva e que, ao mesmo tempo, se encontra na origem da sua filosofia, consideramos oportuno recorrer ao itinerário da abordagem do termo pathos oferecido por Heidegger em O que é a filosofia, que assevera que o pathos se encontra na origem da atividade filosófica. Dito de outro modo, 
iniciamos a exploração da temática partindo da análise do termo pathos, enquanto aquilo de onde a filosofia brota, uma vez que toda filosofia possui, em sua origem, um pathos fundamental (HEIDEGGER, 1999, p. 39). O intuito aqui não é examinálo em todas as suas nuances na obra heideggeriana, apenas recorrer a ele enquanto elemento a designar a condição que se faz presente na origem da filosofia, independentemente de qual seja a concepção metafilosófica assumida, e portanto nos limitamos ao escrito, O que é a filosofia?

No percurso da investigação sobre a natureza da filosofia, o filósofo alemão afirma existir uma dis-posição afetiva fundamental subjacente à reflexão, um ser dis-posto inerente ao filósofo, isto é, ex-posto, iluminado e assim entregue ao serviço daquilo que é. O próprio ato de traduzir pathos como dis-posição se configura como uma estratégia para afugentar uma acepção estritamente psicologizante, porquanto:

\begin{abstract}
Traduzimos habitualmente páthos por paixão, turbilhão afetivo. Mas pháthos remonta a páskhein, sofrer, aguentar, suportar, tolerar, deixar-se levar por, deixar-se con-vocar por. É ousado, como sempre em tais casos, traduzir páthos por dis-posição, palavra com que procuramos expressar uma tonalidade de humor que nos harmoniza e nos con-voca por um apelo. Devemos, todavia, ousar esta tradução porque só ela nos impede de representarmos páthos psicologicamente no sentido da modernidade (HEIDEGGER, 1999, p. 38).
\end{abstract}

A dis-posição se configura fundamentalmente como uma tonalidade afetiva que nos harmoniza e nos convoca por um apelo, para além de uma mera sucessão de sentimentos incidentais, uma vez que:

[...] o nosso comportamento é cada vez dis-posto desta ou daquela maneira. A dis-posição não é um concerto de sentimentos que emergem casualmente, que apenas acompanham a correspondência. Se caracterizamos a filosofia como uma correspondência dis-posta, não-posta, não é absolutamente intenção nossa entregar o pensamento às mudanças fortuitas e vacilações de estados de ânimo (HEIDEGGER, 1999, p. 37).

Identificando o pathos com essa dis-posição, é possível atestar a sua presença já na reflexão dos pensadores gregos, uma vez que Platão, no Teeteto, menciona o pathos do espanto como a origem imperante do filosofar ${ }^{1}$, e Aristóteles, por sua vez,

\footnotetext{
${ }^{1}$ Heidegger cita o texto original, seguido de sua tradução: é verdadeiramente de um filósofo estes pháthos - o espanto, pois não há outra origem imperante da filosofia que este (HEIDEGGER, 1999, p. 37). Algumas traduções, como a de Carlos Alberto Nunes, apresentam o termo "admiração" ao invés de espanto (PLATÃO, 2001, p. 55).
} 
afirma na obra Metafísica que "pelo espanto os homens chegam agora e chegaram antigamente à origem imperante do filosofar" 2 (ARISTÓTELES apud HEIDEGGER, 1999, p. 97). Sendo que a arkhé da filosofia, nos remete ao verbo arkhein, a saber, aquilo que impera, o pathos do espanto é mais do que aquilo de onde nasce o filosofar; é seu elemento motor, propulsor, aquilo que constantemente determina sua marcha, fazendo-se presente em todos os contornos de sua tessitura.

É oportuno ressaltar que o pathos, dis-posição afetiva fundamental, ainda que se configure de diferentes modos na história do pensamento, se faz igualmente presente nos novos modos de estabelecer as questões filosóficas tradicionais, em novos tempos e em novas conjunturas. A filosofia moderna, nesse sentido, se edifica a partir da dis-posição afetiva da dúvida e por conseguinte da confiança na absoluta certeza do conhecimento, a qual passa a ser medida determinante para a verdade. Até mesmo no cenário da filosofia contemporânea, onde evidenciamos a existência de uma pluralidade de concepções acerca da natureza da filosofia com seus respectivos itinerários metodológicos, é possível reconhecer a presença de um pathos, ou melhor, de diversas espécies de pathos, ainda que seja difícil caracterizá-los explicitamente, dado que:

\footnotetext{
Provavelmente impera uma dis-posição afetiva fundamental. Ela, porém, permanece oculta para nós. Isto seria um sinal para o fato de que nosso pensamento atual ainda não encontrou seu claro caminho. $O$ que encontramos são apenas dis-posições do pensamento de diversas tonalidades ${ }^{3}$ (HEIDEGGER, 1999, p. 39).
}

Assimilando o pathos como essa dis-posição geral organizadora e propulsora, presente na cotidianidade cultural e nas formas de existência mais exemplares e caras da história da humanidade, como elemento motor que atravessa todo o espírito de uma época e que se faz interveniente em destinos específicos, nossa exploração da

\footnotetext{
${ }^{2}$ Alguns tradutores, como Vinzenzo Cocco, apresentam o termo "admiração", assim como no caso do texto platônico (ARISTÓTELES, 1984, p. 14).

3 É pertinente salientar que Heidegger afirma a existência de uma dis-posição afetiva fundamental mesmo em tradições filosóficas que se estabelecem a partir de um paradigma explícito de racionalidade, uma vez que: "Muitas vezes e quase por toda parte reina a ideia de que o pensamento que se guia pelo modelo da representação e cálculo puramente lógicos é absolutamente livre de qualquer dis-posição. Mas também a frieza do cálculo, também a sobriedade prosaica da planificação são sinais de um tipo de dis-posição. [...] mesmo a razão que se mantém livre de toda influência das paixões é, enquanto razão, pre-dis-posta para a confiança na evidência lógico-matemática de seus princípios e regras." (HEIDEGGER, 1999, p. 39).
} 
concepção metafilosófica weiliana pressupõe, para que seja concretizada de maneira adequada, a tomada desse elemento fundamental, haja vista que uma filosofia como a de Weil só é devidamente compreendida quando considerada diacronicamente.

Assim, para que nossa tarefa voltada para o modus operandi filosófico de Weil se efetive adequadamente, é imprescindível abordarmos a problemática do sofrimento em sua obra, enquanto um pathos e, logo, como uma condição de possibilidade para assimilar seu percurso filosófico-existencial (Cf. BOSI, 1996).

É oportuno, recordar a referência sempre presente nos estudiosos da autora francesa de que seu itinerário filosófico foi profundamente marcado pelo compartilhamento do sofrimento alheio em diversas situações. Pétrement (1997, p. 67), a esse respeito, recorda que já em seus primeiros escritos existem indícios da identificação de Weil com o sofrimento voluntário. Menciona o núcleo de $O$ belo e $o$ bem, onde a filósofa se debruça sobre a meditação da história de Alexandre atravessando o deserto com seus soldados, acometido pela sede tal como eles, diante do que despeja a água de que dispõe para não ser favorecido diante da situação de seus companheiros, ao passo em que:

[...] tudo se passa na alma de Alexandre; e não se trata para ele senão de manifestar sua humanidade. [...] Deus é inocente, diz Platão. Bastaria portanto ser justo e puro para salvar ao mundo; isso que exprime o mito do Homem-Deus, que resgata os pecados dos homens somente pela justiça sem qualquer ação política. Deve-se, portanto, salvar-se a si mesmo; salvar em si o Espírito, do qual a humanidade exterior é o mito. O sacrifício é a aceitação da dor, a recusa de obedecer o animal em si, e a vontade de resgatar os homens sofredores pelo sofrimento voluntário. Cada santo derramou a água; cada santo recusou toda felicidade que lhe separaria dos sofrimentos dos homens $^{4}$ (OCl, p. 71).

Dessa maneira, compreendemos que este é um “[...] texto que anuncia já toda a vida de Simone ${ }^{5}$ " (PÉTREMENT, 1997, p. 68). O modus vivendi em que se

\footnotetext{
${ }^{4}$ [...] tout se passe dans l'âme d'Alexandre; et il ne s'agit pour lui que de se poser homme. [...] Dieu est innocent, dit Platon. Il suffirait donc d'être juste et pur pour salver le monde; ce qu'exprime le mythe de l'Homme-Dieu, qui rachète les péchés des hommes par la seule justice et sans aucune action politique. II faut donc se sauver soi-même; sauver en soi l'Esprit, dont l'humanité extérieure est le mythe. Le sacrifice est l'acceptation de la douleur, le refus d'obéir à l'animal en soi, et la volonté de racheter les hommes souffrants par la souffrance volontaire. Chaque saint a répandu l'eau; chaque saint a refusé tout bonheur qui le séparerait des souffrances des hommes.

${ }^{5}$ [...] texto que anuncia ya toda la vida de Simone.
} 
transforma sua filosofia possui o pathos do sofrimento como elemento interveniente, sendo pertinente salientar que:

[...] ela não cessou de procurar compartilhar o sofrimento dos outros, abandonando repetidamente sua carreira de professora para trabalhar na fábrica com os trabalhadores, na agricultura com o camponeses ou, em 1936, se alistar na Guerra Civil Espanhola ao lado dos republicanos ${ }^{6}$ (POULIN, 2010, p. 12).

É justamente quando seu percurso intelectual — adequadamente compreendido enquanto articulado com a sua paixão ética (VETÖ, 1997, p. 16) — enquanto se defronta com a realidade de opressão e, à vista disso, de sofrimento, que a verdade assiduamente almejada por ela revela seu aspecto tenebroso, uma vez que:

O processo interior da intelectual Simone Weil vai imbricar-se com a realidade interior da opressão e injustiça no mundo do qual são vítimas muitos milhões de seres humanos. A verdade, também apaixonadamente buscada por ela, começa a mostrar seu rosto sombrio (BINGEMER, 2012, p. 140).

Essa verdade que, por sua vez, se desvela no enredo de eventos concretos da vida de Weil, evidencia a presença interveniente de uma dis-posição afetiva fundamental, de um estar dis-posto constantemente ou, em outras palavras, entregue ao serviço daquilo que é, harmonizando-se às circunstâncias nas quais se está inserido. A atitude de engajar-se na condição proletária pode ser admitida como um ato eminentemente filosófico, em termos da inserção no contexto que subsome uma forma de existência peculiar e possibilita, mediante a participação efetiva na situação dos sujeitos nela inseridos, o encontro com a verdade num sentido eminentemente tangível e não teórico (BINGEMER, 2012, p. 139), em razão de que:

[...] dizia, claramente, nunca ter desejado outra coisa na vida que encontrar essa verdade. Segundo conta sua biógrafa, Simone Pétrement, bem como todos os seus demais biógrafos, isso está absolutamente certo: para assegurar-se de que estava sendo movida pela verdade, Simone Weil sempre procurou agir pela obediência aos acontecimentos ou às circunstâncias. Daí decorre, segundo a biógrafa, sua decisão de ir para a fábrica ${ }^{7}$ (BINGEMER, 2009a, p. 20).

\footnotetext{
${ }^{6}$ [...] n'eut-elle de cesse de chercher à partager la souffrance d'autrui, délaissant à plusieurs reprises sa carrière d'enseignante afin de travailler en usine avec les ouvriers, en agriculture avec les paysans ou, en 1936, de s'enrôler dans la guerre civile d'Espagne aux côtés des républicains. 7 A esse respeito, ver Pétrement (1997, pp. 316-319).
} 
Essa atitude de obediência ou, dito de outro modo, de observância perene ao desígnio de encontrar a verdade, também é apontada por Vetö (1997, p. 38): “ser sempre obediente, e o ser em todas as circunstâncias, era a mais alta aspiração de Simone Weil ${ }^{8}$ ". Essa ação-vontade implica uma atitude de fidelidade por parte da filósofa que dirige sua busca da verdade em um âmbito existencial, a qual não deve resignar-se às consequências inerentes a esse desígnio independentemente da maneira segundo a qual estas se elaboram em seu desfecho, pois:

\begin{abstract}
A busca incansável pela verdade foi o norte de toda a vida e do pensamento de Simone Weil. Busca incessante que a levou para caminhos diversos, tortuosos, sofridos, contraditórios e místicos. Manter-se na trilha que levaria à verdade não era apenas uma opção, mas uma vocação semelhante a um mandato divino ${ }^{9}$, o qual não poderia recusar, apenas obedecer. Obediência levada às últimas consequências para não ser infiel à missão de encontrar a verdade (MARTINS, 2013, p. 25).
\end{abstract}

Sendo assim, a articulação conceitual que configuramos para compreender a temática em questão deve se dar de maneira diacrônica, isto é, deve ser acompanhada de uma exploração dos elementos históricos e dos respectivos contextos onde esses mesmos conceitos têm seu ambiente de constituição, ao passo em que é oportuno reafirmar, com Pérez ${ }^{10}$ (2009, p. 78), que:

Nela se dá sempre uma clara sintonia entre a experiência e a escrita, entre pensamento e ação ou entre a vida e a obra. Razão que impede de abordar suas contribuições de forma exclusivamente sistemática, e nos obriga a adentrar em sua vida para compreender sua obra.

Para tratar os elementos históricos indispensáveis à assimilação da constituição do pathos do sofrimento na filosofia weiliana, bem como a outros conceitos que são

\footnotetext{
${ }^{8}$ Être toujours obéissante et l'être dans tout les circonstances, était la plus haute aspiration de Simone Weil.

${ }^{9}$ A despeito da expressão "mandato divino" presente na citação de Martins, não acreditamos que o autor esteja sugerindo uma intervenção divina direta nos acontecimentos da vida de Simone Weil, pois isso iria de desencontro com a sua concepção de Deus que, enquanto criador, se retira, abdicando de interferir na realidade e permitindo a existência de uma criatura dotada de autonomia (VETÖ, 1997, p. 22). Ao invés disso, é mais provável que o autor tenha aqui o intuito de salientar a radicalidade inerente ao projeto filosófico de Weil de se empenhar na busca da verdade até as últimas consequências. No tocante à temática da sua concepção de Deus, retornaremos a ela com mais acuidade e possibilidade de desenvolvimento no terceiro capítulo de nosso trabalho. Conferir também Gambellieri, 2005; García, 2015.

${ }^{10}$ Emilia Bea Pérez é professora e pesquisadora da Universidade Internacional Menéndez Pelayo e autora do artigo Simone Weil: esperar na ausência de esperança.
} 
fundamentais para o seu devido entendimento, devemos compreender a dimensão especulativa e a dimensão concreta em sua indissociabilidade no itinerário filosóficoexistencial weiliano, uma vez que, como reconhece Moraes $^{11}$ (2015, p. 14):

[...] a experiência não se forja diante de um acontecimento visto como banal, ordinário, corriqueiro, dissimilado e ignorado por sua irrelevância; a experiência se dá no marco da capacidade de transformar o acontecimento, independentemente de sua dimensão ou efeito, em um acontecimento significativo. Por isso a exigência do tempo, já que o contato com situações capazes de produzir significado se dá no transcurso do ciclo vital; e, além disso, eles tendem a um viés cumulativo: quanto mais experiência, maior a potencialidade de assimilar acontecimentos experienciáveis.

Ademais, em alguns escritos, Weil se dedica significativamente a explicitar as ressonâncias oriundas de seu contato com a realidade proletária e a salientar o peso das consequências dessa situação em sua vida ${ }^{12}$, bem como a enfatizar os impactos dessa experiência em seu profundo sentimento de dilaceramento frente ao contato com a opressão ${ }^{13}$.

\section{A paixão ética de Simone Weil: a condição operária, a guerra e as primícias da concepção de sofrimento}

Em primeira instância, é pertinente salientar como Pétrement (1997, p. 88) que, para Weil, o ser humano mais plenamente realizado, mais verdadeiramente humano, é aquele que é, simultaneamente, trabalhador manual e pensador. Além disso, segundo ela, na época da Escola Normal, Weil já almejava o trabalho operário, quiçá desde seus dez anos de idade, como se pode conferir em carta que redigiu a Marcel Martinet em $1934^{14}$ (PÉTREMENT, 1997, p. 135).

\footnotetext{
${ }^{11}$ Alexandre Santos de Moraes é professor e pesquisador da Universidade Federal Fluminense, autor do artigo A pedagogia da experiência humana: Aquiles e o sofrimento que ensina.

${ }^{12}$ Ver, por exemplo, Três cartas a Albertine Thévenon (1934-1935) e Diário da fábrica, ambos contidos em CO.

${ }^{13} \mathrm{~A}$ menção posterior de Weil à experiência da fábrica e seus efeitos é pungente, por exemplo, em Autobiografia espiritual, contido em AD.

14 Vale ressaltar que Pétrement (1997, p. 274) reconhece que Weil sentia uma inferioridade em relação aos trabalhadores manuais antes de seu engajamento na condição operária, temendo, ademais, ser vista como uma mera intelectual tecendo reflexões desenraizadas da dimensão concreta da vida, um dos motivos que a faz optar por abandonar a docência e se engajar no trabalho proletário.
} 
Dessa maneira, longe de ser um gesto intelectual romântico, o propósito da filósofa para se engajar na condição operária se elabora fundamentalmente como uma tentativa de compreender a relação da técnica moderna com os aspectos essenciais da civilização de então (GABELLIERI, 2001, p. 15), além do que:

\begin{abstract}
[...] no plano do pensamento teórico, havia chegado a um beco sem saída. Desde há muito tempo vinha tentando conciliar a organização que exige a sociedade industrial com as condiç̃̃es de trabalho e de vida próprias de um proletariado livre. Como coordenar os trabalhos sem oprimir aos trabalhadores? Uma questão para a qual não havia encontrado resposta. Deve ter pensado que, onde a reflexão teórica não encontrava solução, o contato com seu objeto poderia sugerir-lhe alguma. $\mathrm{O}$ objeto era essa miséria à qual havia de encontrar remédio. Pessoalmente submergida nessa miséria, veria com melhor clareza que remédios poderiam resultar apropriados. E, depois de tudo, para falar dessa questão havia de conhecê-la ${ }^{15}$ (PÉTREMENT, 1997, p. 318).
\end{abstract}

Sendo assim, entre dezembro de 1934 e agosto de 1935, Weil desempenhou atividades como operária fabril, atuando, respectivamente, nas fábricas da Alsthom, Carnaud e Renault. Os relatos de Weil sobre esse período são a expressão de uma reflexão enraizada na vivência de uma condição dilacerante de existência, a despeito de uma especulação desprovida de qualquer ressonância com a vida concreta, uma vez que, como ela própria declara a Albertine Thévenon:

\begin{abstract}
Essa experiência, que corresponde de muitas maneiras ao que eu esperava, ainda difere por um abismo: é a realidade, não mais a imaginação. Ela mudou para mim não tal ou tal das minhas ideias (muitas foram pelo contrário confirmadas), mas infinitamente mais, toda a minha perspectiva sobre as coisas, o sentimento mesmo que eu tenho da vida. [...] uma vez lá dentro, como é outra coisa! [...] um lugar onde a gente se choca duramente, dolorosamente, mas mesmo assim alegremente com a verdadeira vida ${ }^{16}(\mathrm{CO}$, p. 13$)$.
\end{abstract}

\footnotetext{
15 [...] en el plano del pensamiento teórico, había llegado a un callejón sin salida. Desde hacia mucho tiempo venía intentando conciliar la organización que exige la sociedad industrial con las condiciones de trabajo y de vida proprias de un proletariado libre. Como coordinar los trabajos sin oprimir a los trabajadores? Una question para la que no había encontrado respuesta. Debió de pensar que, allí donde la reflexión teórica no encontraba solución, el contacto con su objeto podría sugerirle una. El objeto era esa miseria a la que había que encontrar remedio. Personalmente sumergida en esa miseria, vería con mayor claridad qué remedios podían resultar apropriados. $Y$, después de todo, para hablar de esa cuestión, había que conocerla.

${ }^{16}$ Cette expérience, qui correspond par bien des côtés à ce que j'attendais, en diffère quand même par un abîme: c'est la réalité, non plus l'imagination. Elle a changé pour moi non pas telle ou telle de mes idées (beaucoup ont été au contraire confirmées), mais infiniment plus, toute ma perspective sur les choses, le sentiment même que j'ai de la vie. [...] une fois dedans, comme c'est autre chose! [...]un endroit où on se heurte durement, douloureusement, mais quand même joyeusement à la vraie vie.
} 
Num escrito intitulado $A$ vida e a greve dos metalúrgicos, Weil descreve explicitamente vários elementos correspondentes ao dia-a-dia vivenciado no âmbito do trabalho fabril, como as ocasiões de receber o salário e sensações como a fome, o medo, a sujeição e a fadiga, acompanhados do sentimento de que esse estado tinha prazo indeterminado, dado que:

A fadiga, esmagadora, amarga, por momentos dolorosa ao ponto que a gente desejaria a morte. Todo mundo, em todas as situações, sabe o que é estar cansado, mas esta fadiga, ela precisaria de um nome à parte. [...] Um dia como virá outro no dia seguinte, e depois de amanhã, sempre ${ }^{17}$ (CO, p. 146-147).

Num dos relatos contidos no Diário da fábrica, Simone Weil alude à crueldade da cadência ininterrupta de movimentos repetitivos recordando que um dos seus efeitos consistia na redução do operário ao estado de inconsciência acerca de suas próprias ações, o que ocasionava aquilo que ela denomina "estado de besta de carga", em termos de uma eminente segregação entre atividade manual e atividade intelectual, porquanto:

Sinto profundamente a humilhação deste vazio imposto ao pensamento. [...] Ritmo ininterrupto. O trabalho manual comporta isso sempre? A máquina dispensa o pensamento de intervir, por pouco que seja, mesmo pela simples consciência das operações realizadas; o ritmo lhe impede ${ }^{18}(\mathrm{CO}, \mathrm{pp}$. 58.106).

A árdua rotina de trabalho operário e as sensações a ela inerentes, como medo e a angústia ininterruptos e o conjunto de elementos que circunscrevem o processo de despersonalização infernal, se desmembra, em última instância, numa submissão instantânea, efeito da perda do sentimento de dignidade intensificada pela humilhação. Em algumas ocasiões, como quando ela descreve a organização da fábrica, esse mesmo processo é denominado escravidão, uma vez que:

\footnotetext{
${ }^{17}$ La fatigue, accablante, amère, par moments douloureuse au point qu'on souhaiterait la mort. Tout le monde, dans toutes les situations, sait ce que c'est que d'être fatigué, mais pour cette fatigue-là, il faudrait un nom à part. [...] Une journée comme il y en aura une encore le lendemain, le surlendemain, toujours.

${ }^{18}$ Sens profondément l'humiliation de ce vide imposé à la pensée. [...] Rythme ininterrompu. Le travail à la main le comporte-t-il jamais? La machine dispense la pensée d'intervenir si peu que ce soit, même par la simple conscience des opérations accomplies; le rythme le lui interdit.
} 
A gente se esgota, se mata por $2 \mathrm{~F}$ por hora. [...] A gente se mata sem nenhum resultado, seja subjetivo (salário), seja objetivo (obra realizada), que corresponda às dores. Aí é que a gente se sente realmente escravo, humilhado até o mais profundo de si mesmo ${ }^{19}$ (CO, p. 66).

Por conseguinte, o substrato desse estado no qual os sujeitos inseridos na condição operária eram acometidos, é definido, pela filósofa, como coisificação, a saber, como uma circunstância na qual o ser humano é reduzido a um estado de coisa, de matéria inerte, de algo incapaz de desempenhar nada além de mera sucessão de movimentos mecânicos inconscientes, o equivalente a desumanização, haja vista que:

\begin{abstract}
O que conta em uma vida humana, não são os eventos que dominam o curso dos anos - ou mesmo dos meses - ou mesmo dos dias. É a maneira pela qual se encadeia um minuto ao seguinte, e o que custa a cada um em seu corpo, em seu coração, em sua alma - e sobretudo no exercício da sua faculdade de atenção ${ }^{20}$ - para efetuar minuto por minuto esse encadeamento ${ }^{21}$ (CO, p. 111).
\end{abstract}

Nesse mesmo âmbito de reflexão, ela afirma: "a gente é uma coisa entregue à vontade de outro 22 " (CO, p. 147) ${ }^{23}$. Longe de nos precipitarmos numa mera descrição

${ }^{19}$ On s'épuise, on se crève pour $2 \mathrm{~F}$ l'heure. [...]On se crève sans qu'aucun résultat, soit subjectif (salaire), soit objectif (oeuvre accomplie), corresponde à la peine. Là, on se sent vraiment esclave, humilié jusqu'au plus profond de soi.

20 Vetö (1997, p. 45), a esse respeito, recorda que no texto citado acima, um dos elementos fundamentais que Weil elenca para definir o estado no qual os operários se encontravam no âmbito do seu trabalho era a ausência da atenção, faculdade que assegura o conhecimento objetivo do mundo e o domínio de si, impossibilitada pela cadência da atividade fabril.

${ }^{21}$ Ce qui compte dans une vie humaine, ce ne sont pas les événements qui y dominent le cours des années - ou même des mois - ou même des jours. C'est la manière dont s'enchaîne une minute à la suivante, et ce qu'il en coûte à chacun dans son corps, dans son coeur, dans son âme - et pardessus tout dans l'exercice de sa faculté d'attention - pour effectuer minute par minute cet enchaînement.

${ }^{22}$ On est une chose livrée à la volonté d'autrui.

${ }^{23}$ É pertinente ressaltar que Weil se refere aos mecanismos da ciência moderna, modeladores da estrutura industrial de então, como a causa fundamental da conversão do trabalho num meio de escravidão. Segundo ela, o verdadeiro problema, não suscetível de resolução pelo fato de não chegar nem mesmo a ser considerado, era o de encontrar um método de organização do trabalho que fosse aceitável tanto para a produção quanto para o trabalho e para o consumo. O substrato das reflexões edificadas por ela sobre essa temática estão presentes no texto intitulado $\mathrm{A}$ racionalização, oriundo de um discurso da filósofa francesa para um auditório operário em 23 de fevereiro de 1937, e do qual se conservou um excerto colhido por um ouvinte. Para uma explanação mais aprofundada, ver CO (p. 182-196). É também nesse contexto temático que surge sua proposta da edificação de uma cultura operária, que se constituiria no produto da articulação entre ciência, trabalho manual e espiritualidade que possibilitaria ao operário ter uma rotina de trabalho libertadora e não escravizadora e dilacerante como ocorria no contexto que subsome a sua experiência na atividade fabril. Ademais, vale recordar que ela refletiu com acuidade sobre a possibilidade de encontrar pontos comuns de afinidade entre ciência e espiritualidade, 
de relatos biográficos pontuais desprovidos de profundidade especulativa, a referência às passagens citadas se nos impõem pela necessidade de salientar a gênese empírica de uma especulação ulteriormente desenvolvida, que descreve a situação real das pessoas inseridas na condição operária de então.

Outro contexto que é pertinente recordar na exploração da configuração da concepção weiliana do sofrimento é o fato dela ter participado na Guerra Civil Espanhola entre agosto e setembro de 1936, mais precisamente quando se encontra em Barcelona e posteriormente no fronte de Aragon junto aos anarquistas de Durruti (POULIN, 2010, p. 12).

No contexto desta experiência como militante, impulsionada pelos ideais revolucionários de solidariedade, Weil se depara com a situação, certamente inesperada, na qual a condição dos submissos camponeses, aparentemente afastados da motivação genuína da guerra, mostravam que neles estavam ausentes as preocupações primárias dos milicianos, os quais eram movidos mais pelo ideal de aniquilação do outro do que de comprometimento sociopolítico factual (BINGEMER, 2007, p. 82), o que culmina no seu diagnóstico de que:

\footnotetext{
O que movia os revolucionários não era o magnífico ideal de liberdade e justiça, conforme imaginava; descobriu neles crueldade, indiferença ou também aprovação das atrocidades. Não se tratava de uma justa luta de camponeses famintos contra proprietários de terra e um clero cúmplice, mas de uma guerra de interesses entre blocos internacionais (BORDIN, 1996, p. 526).
}

Um fator que corrobora significativamente com sua desmotivação com relação ao engajamento na guerra é sua leitura de Les grands cimitières sous la lune ${ }^{24}$, a partir do que expressa seu desapontamento acerca dos ideais que a levaram a arriscar a vida, uma vez que assevera:

[...] quando as autoridades temporais e espirituais criam uma subcategoria de seres humanos, cujas vidas não têm valor, então não há nada mais natural para o homem que matar. Quando se sabe

concebendo-os como dois âmbitos da experiência humana que podem se relacionar desde que sejam corretamente assimilados. Enfim, tudo isso irá culminar com o seu pensamento sobre uma recriação do homem e da cultura moderna, onde "[...] a ciência, a literatura e a espiritualidade não poderiam se separar de um projeto novo do ser humano" (JULIANO, 2009, p. 7). Para uma exploração introdutória destes elementos, o que, em virtude de nosso escopo temático, não dispomos de espaço para desempenhar no âmbito desta fundamentação teórica, ver Juliano (2009), Bosi (2009) e Bingemer (2012).

${ }^{24}$ Relato sobre a Guerra da Espanha escrito pelo autor francês católico George Bernanos. 
que é possível matar sem se arriscar ao castigo ou à reprovação, se mata; ou ao menos se cercam de sorrisos encorajadores aqueles que matam (WEIL apud BINGEMER, 2007, p. 82).

Adentraremos, agora, no domínio da investigação daquilo que serviu como chave interpretativa dos fenômenos sociais para Simone Weil, a saber, a noção de força (BINGEMER, 2007, p. 89).

\section{A llíada ou o poema da força}

A reflexão que Weil configura para expressar suas ressonâncias, oriundas do contato com a realidade de opressão em seu engajamento sociopolítico, é consideravelmente marcada por sua leitura e apreciação da Ilíada ${ }^{25}$, o que Bordin (1996, p. 527) nos auxilia a evidenciar, posto que:

llíada ou o poema da força, ao mesmo tempo, um belo comentário ao poema homérico e uma lúcida meditação sobre a natureza da força em sua representação extrema: a guerra. Não se trata tanto da guerra de heróis, mas da dura e desapiedada lógica dessa força arrasadora a que ninguém foge, nem vencidos, nem vencedores.

Dessa forma é oportuno reconhecer que as experiências traumáticas e as reflexões ulteriormente configuradas conduziram Weil a acolher, em sua visão de mundo, a dimensão do trágico (BORDIN, 1996, p. 528), em termos do que reconhece o "[...] limite do pensamento racional, que, de fato, não consegue dar conta das realidades contraditórias em que está envolvida nossa existência” (BORDIN, 1996, p. 529), o que se faz evidente em sua afirmação de que "a contradição essencial da condição humana é que o homem está submisso à força e deseja a justiça26" (OL, p. 148), o que também é apontado por Stefania Carta Macaluso em sua obra Il metaxú: la filosofia di Simone Weil, quando assevera:

A filosofia como é compreendida está mais interessada em suscitar problemas que a oferecer soluções, segundo um modelo de especulação que não se presta a nenhuma manipulação do pensamento, que se encaminha, ao invés de atravessar um rigor lógico-argumentativo, para a

\footnotetext{
${ }^{25}$ Constituindo-se num dos principais poemas épicos gregos, atribuída a Homero (IX-VIII a. C.), consiste na narração dos eventos ocorridos durante o último ano da guerra de Troia.

${ }^{26}$ La contradiction essentielle de la condition humaine, c'est que l'homme est soumis à la force, et désire la justice.
} 
inexauribilidade problemática da procura, contrariamente à presunção de completude sistemática própria do racionalismo de ontem e de hoje ${ }^{27}$ (MACALUSO, 2003, p. 14).

É desse contexto de reflexão que emerge o conceito de forŗa, tal como Weil o define, a saber, aquilo perante o que "[...] a carne dos homens se contrai" (SG, p. 379) ${ }^{28}$. Examinando o horizonte semântico deste termo no texto, percebemos como é possível sua articulação com as ressonâncias oriundas da experiência de Weil na fábrica e na guerra e, por conseguinte, com a oportunidade de recorrer a ele como recurso para interpretar os fenômenos que marcam a vida, dado que:

\begin{abstract}
A força é aquilo que transforma quem quer que lhe seja submetido em uma coisa. Quando ela se exerce até o fim, transforma o homem em coisa, no sentido mais literal da palavra, porque o transforma em cadáver. Era uma vez alguém e, um instante depois, não há mais ninguém (SG, p. 379).
\end{abstract}

Ainda que consideremos a asserção de Pétrement (1997, p. 567) de que, à primeira vista, a reflexão contida em A Ilíada ou o poema da força se revela apenas como uma tentativa de compreender a Ilíada, é pertinente salientar que nossa recorrência a ele tem por objetivo estabelecer o conceito de força com a finalidade de empregá-lo em articulação com a experiência weiliana do sofrimento e, por conseguinte, como chave interpretativa dos fenômenos sociais como o faz Bingemer (2007, p. 89).

É na urdidura desse escrito, como nos recorda Vetö (1997, p. 78), que Weil se dispõe a analisar a força sob sua forma mais horrível, a saber, a violência humana, causa desse processo de despersonalização infernal do ser humano. Isso nos permite compreender que estes dois termos, força e violência, têm uma significativa correspondência nos escritos weilianos, em razão de que:

Em todos os seus escritos, Simone Weil utiliza indiferentemente os conceitos de "força" e "violência", de tal maneira que podemos afirmar que ela chega a identificar plenamente um e outro. Às vezes faz afirmações lançando mão de um conceito, como quando diz: "a violência esmaga

\footnotetext{
${ }^{27}$ La filosofia così intesa è interessata più a suscitare problemi che ad offrire soluzioni, secondo un modello di speculazione che non si presta a nessuna manipolazione del pensiero, che s'incammina, piuttosto, attraverso un estremo rigore logico-argomentativo, verso l'inesauribilità problematica della ricerca, contrariamente ad ogni presunzione di compiutezza sistematica propria dei razionalismi di ieri e di oggi.

${ }^{28}$ A edição de La source grecque - A fonte grega - que aqui utilizamos é a contida na coletânea Simone Weil: a condição operária e outros estudos sobre a opressão organizada por Therezinha Gomes Garcia Langlada. Ver Referências.
} 
aqueles que ela toca". Mas dentro do contexto global da reflexão, a palavra "violência" tem o mesmo significado que "força" [...] (BINGEMER, 2009a p. 117).

É pertinente, portanto, que não nos limitemos à análise do conceito de força, mas que nos atentemos ao conceito de violência em algumas de suas ocorrências nas obras de Weil para que possamos assimilar com maior precisão os aspectos dessa correspondência. A filósofa francesa concebe a violência como algo inerente à natureza animal existente no ser humano, a qual pode, por sua vez, condicionar as suas atitudes em sua relação com o outro, ao passo em que:

Todos os homens trazem consigo essa natureza animal. Ela determina sua atitude a respeito dos seus semelhantes com ou sem seu conhecimento e sua adesão. Assim, às vezes, sem que o pensamento se dê conta de nada a natureza animal em um homem sente a mutilação na natureza animal em um outro e age em consequência. O mesmo para todas as situações possíveis e as reações animais correspondentes. Essa necessidade mecânica possui todos os homens a todos os momentos $^{29}$ (AD, pp. 57-58).

A pensadora assevera que o princípio da violência reside na vontade (PG, p. 125), e que é necessário tomar uma atitude de adestramento para com esse mesmo princípio, almejando moderar os comandos dessa natureza animal do ser humano, dado que:

[...] deve-se também, em uma medida limitada, mas na plenitude dessa medida, usar violentamente desse princípio violento; obrigar-nos por violência a agir como se não tivéssemos tal desejo, tal aversão, tentar persuadir a sensibilidade, obrigando-a a obedecer. Ela se revolta então, e deve-se suportar essa revolta, degustá-la, saboreá-la, aceitá-la como uma coisa exterior [...] $]^{30}$ (PG, p. 125).

Sendo assim, é possível dizer que é justamente quando não ocorre essa atitude de adestramento e, por conseguinte, que a violência humana é exercida e prolifera,

\footnotetext{
${ }^{29}$ Tous les hommes portent en eux cette nature animale. Elle détermine leur attitude à l'égard de leurs semblables avec ou sans leur connaissance et leur adhésion. Ainsi parfois sans que la pensée se rende compte de rien la nature animale dans un homme sent la mutilation de la nature animale dans un autre et réagit en conséquence. De même pour toutes les situations possibles et les réactions animales correspondantes. Cette nécessité mécanique tient tous les hommes à tous moments; ils y échappent seulement à proportion de la place que tient dans leurs âmes le surnaturel authentique. 30 il faut aussi, dans une mesure limitée, mais dans la plénitude de cette mesure, user violemment de ce principe violent; se contraindre par violence à agir comme si on n'avait pas tel désir, telle aversion, essayer de persuader la sensibilité, en la contraignant d'obéir. Elle se révolte alors, et il faut subir passivement cette révolte, la goûter, la savourer, l'accepter comme une chose extérieure.
} 
que o sofrimento e o processo de despersonalização são efetivados, dito de outro modo, que pessoas são transformadas em coisas, porquanto:

[...] um ponto que será central nas reflexões de Simone Weil sobre a violência: seu poder de reduzir o ser humano a uma coisa. O homem submetido à ameaça de morte, que é em última análise a sanção suprema de toda autoridade, pode tornar-se mais manipulável que a matéria inerte. E como os que comandam estão sempre dispostos a pisotear a dignidade dos outros, vão transformando os homens em coisas cada vez mais dúcteis e manipuláveis (BINGEMER, 2007, p. 88).

Ainda sobre a força, ou melhor, sobre sua forma como violência humana, Weil recorda que "o elemento que introduz a ruptura em qualquer equilíbrio, físicohumano-social, é a força. Essa é irreversível e incontrolável. [...] enganam-se os homens que acreditam ser possível controlar seus efeitos” (BORDIN, 1996, p. 527), e denuncia a atitude daqueles que se abstém de considerá-la, ou que buscam amenizar sua intensidade conferindo-lhe outros nomes, o que, certamente, não faz com que aqueles que realmente tiveram ou têm um contato direto com o seu império desconheçam seus efeitos e suas ressonâncias reais, uma vez que:

\begin{abstract}
Hoje vemos muitas pessoas que honram acima de tudo a força, sejam aqueles que dão a ela esse nome ou outros nomes com uma sonoridade mais agradável. Também vemos muitos, embora em número rapidamente decrescente, que desprezam a força. Eles ignoram seus efeitos e poder. Eles mentem para si mesmos se necessário por não se instruírem sobre isso. Mas quem conhece toda a extensão do império da força e, ao mesmo tempo, a despreza? ${ }^{31}$ (IPC, p. 49).
\end{abstract}

Outro efeito inerente à incidência da força que a filósofa francesa não hesita em considerar é o seu poder de acometer, de petrificar tanto aqueles que a exercem quanto aqueles que a sofrem, não existindo, no âmbito do seu império, nenhum ser humano que não seja, em alguma medida, tocado por seu potencial destruidor, porquanto:

Hoje, diante de um ato de violência, alguns concedem sua simpatia a quem exerce a violência, outros a quem a sofre. Há covardia nas duas atitudes. Os melhores entre os gregos, a começar pelo poeta ou pelos poetas da llíada, sabiam que tudo o que exerce ou sofre força está paralelamente e

\footnotetext{
${ }^{31}$ Aujourd'hui on voit beaucoup de gens qui honorent par-dessus tout la force, soit qu'ils lui donnent ce nom ou d'autres noms pourvus d'une sonorité plus agréable. On en voit aussi beaucoup, quoique en nombre rapidement décroissant, qui méprisent la force. C'est qu'ils en ignorent les effets et la puissance. Ils se mentent à eux-mêmes au besoin pour ne pas s'instruire là-dessus. Mais qui connaît toute l'étendue de l'empire de la force et en même temps la mépris?
} 
na mesma medida sujeito ao seu império degradante. Se se maneja a força ou se se está ferido por ela, de todas as maneiras, seu contato petrifica e transforma um homem em coisa ${ }^{32}$ (IPC, p. 50).

Essa mesma caracterização da força — que na citação acima corresponde à obra Intuições pré-cristãs, aparece, destarte em A Ilíada ou o poema da força, onde, após destacar a propriedade que ela possui de converter os que são tocados por ela em mudos ou surdos, Weil (SG, p. 398) assevera:

Tal é a natureza da força. O poder que ela possui de transformar os homens em coisas é duplo, e se exerce no sentido de ambos os lados; petrifica diferentemente, mas igualmente, as almas dos que a sofrem e dos que a manejam.

Mediante a ocorrência de expressões como "transformação dos homens em coisas" e "matéria inerte" 33 , é possível e até mesmo impõe-se-nos como tarefa imprescindível, interpretar esses escritos em articulação com a experiência weiliana da opressão na realidade da fábrica e da guerra, o que confirma as exortações de seus estudiosos de que não é verdadeiramente possível conceber sua filosofia de maneira profícua a despeito da consideração de seu itinerário existencial. Ademais, ela assevera que para aqueles que estão submetidos ao jogo da força, a relação entre a morte e o futuro possui uma peculiaridade significativa em relação a outros seres humanos. Enquanto que para os seres humanos em geral a morte consiste num limite determinado previamente ao futuro, para os primeiros, a saber, os participantes factuais da guerra, a morte corresponde ao próprio futuro, dado que:

Desde que a prática da guerra torna sensível a possibilidade de morte que cada minuto contém, o pensamento se torna incapaz de passar de um dia ao que segue sem atravessar a imagem da morte. O espírito fica então tenso, de uma forma que ele não aguenta senão por pouco tempo; mas cada nova alvorada traz a mesma necessidade; os dias acrescentados aos dias formam anos. A alma sofre a violência todos os dias (SG, p. 395).

32 Aujourd'hui, devant un acte de violence, les uns accordent leur sympathie à celui qui exerce la violence, les autres à celui qui la subit. Il y a de la lâche-té dans les deux attitudes. Les meilleurs parmi les Grecs, à commen-cer par le ou les poètes de l'lliade, savaient que tout ce qui exerce ou subit la force est pareillement et dans la même mesure soumis à son empire dégradant. Qu'on manie la force ou qu'on soit blessé par elle, de toutes manières son contact pétrifie et transforme un homme en chose.

${ }^{33}$ No contexto da reflexão sobre a guerra no escrito citado acima, Weil afirma que os homens encontram-se despojados das faculdades calcular, trabalhar e executar tarefas de maneira consciente, mas, pelo contrário, estão precipitados no nível "[...] ou de matéria inerte que é só passividade, ou das forças cegas que são apenas impulso" (SG, p. 398). 
É mister, portanto, reconhecer que ela compreende que a violência da guerra se constitui num malefício não apenas para aqueles que são mortos, senão também para os exterminadores, os quais são acometidos por um certo espírito de destruição do outro, sobre o que ela declara: "existe na guerra um contágio, uma embriaguez à qual é impossível resistir sem uma força de alma que tenho que acreditar que é excepcional, pois não a encontrei em parte alguma” (WEIL apud BINGEMER, 2007, p. 82).

Como nos recordam Poulin (2010, p. 12) e Martins (2013, p. 17), é nesse contexto que emerge o conceito de malheur, um dos mais caros à filosofia de Simone Weil, realidade necessária para adentrarmos na profundidade especulativa que a filósofa edifica para expressar sua concepção acerca do sofrimento. Compreender em que consiste o malheur nos dará condição de possibilidade de assimilar com mais precisão a configuração do pathos do sofrimento em Weil.

\section{O malheur}

Em Cadernos, Weil declara: "malheur. palavra admirável, sem equivalentes noutras línguas ${ }^{34 "}$ (OC VI 2, p. 72). Assim empregou o termo que expressa o substrato da sua concepção acerca do sofrimento, em termos do que compreendemos Martins (2013, p. 17), quando assevera que "ela escreveu em francês e escolheu o termo malheur para se referir a essa profunda experiência de sofrimento, e que podemos traduzir livremente, mas apenas de forma aproximativa, por "desgraça" ou "desventura"”35.

É pertinente, portanto, reconhecer que a experiência weiliana do sofrimento se desmembra no malheur, definido por ela como um desenraizamento integral da vida humana, acometendo todas as faculdades do sujeito e concretizando o processo de despersonalização infernal implicado pela violência no contexto do império da força. Dadas a complexidade e a profundidade inerentes a esse conceito, optamos por citar

\footnotetext{
${ }^{34}$ Malheur, mot admirable, pas d'équivalent dans les autres langues.

35 Poulin (2010, p. 5), por exemplo, no resumo em inglês de seu escrito Le sacrement du malheur chez Simone Weil, utilizou o termo "calamity" na tradução de malheur. De acordo com as orientações exegéticas de Martins, bem como da própria autora, optamos por manter seu emprego original.
} 
na íntegra a passagem que constitui na definição mais explícita que Weil lhe confere, a saber:

\begin{abstract}
No domínio do sofrimento, o malheur é uma coisa à parte, específica, irredutível. É qualquer outra coisa que não o simples sofrimento. Ele captura a alma e a marca, no âmago, uma marca que pertence a ele, a marca da escravidão. [...] O malheur é inseparável do sofrimento físico, ainda que bastante distinto dele. No sofrimento, tudo o que não está relacionado à dor física ou algo parecido é artificial, imaginário, e pode ser destruído por uma disposição adequada de pensamento. [...] o malheur é um desenraizamento da vida, um equivalente mais ou menos atenuado da morte, feito irresistivelmente presente à alma pelo golpe ou pela apreensão imediata da dor física. Se a dor física está completamente ausente, não há malheur para a alma, porque o pensamento se volta a qualquer outro objeto. O pensamento foge do malheur tão prontamente, tão irresistivelmente quanto um animal foge da morte. Não há neste mundo senão a dor física e nada mais que tenha a propriedade de acorrentar o pensamento; desde que assimilemos à dor física certos fenômenos difíceis de descrever, mas corporais, que lhe são rigorosamente equivalentes. A apreensão da dor física, especialmente, é deste tipo ${ }^{36}$ (PSO, p. 61).
\end{abstract}

Compreendemos que o malheur constitui num acometimento do sujeito em todas as instâncias, desde os elementos psicológicos até a destituição do sentimento de pertença a uma coletividade, correspondendo à “[...] pior experiência de degradação possível ao ser humano. Algo que fere a pessoa retirando-a de todas as suas seguranças e deixando-a entregue à miséria e à condição humana frágil" (MARTINS, 2013, p. 21), para além, portanto, do sofrimento meramente físico, porquanto assimilamos que:

Malheur é diferente do sofrimento, mas os dois estão juntos. No malheur, encontra-se também o sofrimento, mas o contrário não é verdadeiro. "O malheur é inseparável do sofrimento físico, no entanto, é totalmente distinto". É distinto porque o sofrimento, como também dor física, é ainda pouco para afetar a alma do ser humano (MARTINS, 2013, p. 200).

\footnotetext{
${ }^{36}$ Dans le doumaine de la souffrance, le malheur est une chose à part, spécifique, irréductible. Il est tout l'autre chose que la simple souffrance. Il s'empare de l'âme et la marque, jusqu'au fond, d'une marque qui n'appartient qu'à lui, la marque de l'esclavage. [...] Le malheur est inséparable de la souffrance physique, et pourtant tout à fait distinct. Dans la souffrance, tout ce qui n'est pas lié à la douleur physique ou à quelque chose d'analogue est artificiel, imaginaire, et peut être anéanti par une disposition convenable de la pensée. [...] le malheur est un déracinement de la vie, un équivalent plus ou moins atténué de la mort, rendu irrésistiblement présent à l'âme par l'atteinte ou l'appréhension immédiate de la douleur physique. Si la douleur physique est tout à fait absente, il n'y a pas malheur pour l'âme, parce que la pensée se porte vers n'importe quel autre objet. La pensée fuit le malheur aussi promptement, aussi irrésistiblement qu'un animal fuit la mort. Il n'y a ici-bas que la douleur physique et rien d'autre qui ait la propriété d'enchaîner la pensée; à condition qu'on assimile à la douleur physique certains phénomènes difficiles à décrire, mais corporels, qui lui sont rigoureusement équivalents. L'appréhension de la douleur physique, notamment, est de cette espèce.
} 
Gabellieri (2001, p. 60), a esse respeito, tece oportunas considerações, dado que esclarece a diferença entre malheur e aquilo que seria um "semi-malheur", que é o sofrimento de ordem estritamente física. As palavras da filósofa confirmam a descrição do comentador, uma vez que "por outro lado, uma dor somente física é muito pouca coisa e não deixa qualquer traço na alma ${ }^{37 "}$ (PSO, p. 62), e que "é de outro modo com um sofrimento físico muito longo ou muito frequente. Mas um tal sofrimento é frequentemente outra coisa que não um sofrimento; é frequentemente um malheur 38" (PSO, p. 62), uma vez que:

\begin{abstract}
Para se ter o malheur, não se conta necessariamente a intensidade da dor física, mas, sim, se a pessoa se reconhece em um estado extremamente forte de violência contra o ser, um desespero dentro do qual não consegue fazer nada, restando apenas aceitar e sofrer, pois vê todas as dimensões de sua existência feridas violentamente por uma força sem medidas que destrói as raízes de sustentação do ser. Para acontecer o malheur, nada na vida humana deixa de ser afetado (MARTINS, 2013, p. 200-201).
\end{abstract}

Compreendemos, destarte, que o malheur não se limita à dimensão psicológica e nem à física, mas as duas são afetadas no âmbito de uma dimensão social que as subsome, causa da precipitação do sujeito num estado angustiado e humilhante, ao passo em que entendemos que:

\begin{abstract}
Não há verdadeiramente malheur senão se o evento que apreendeu uma vida e a desenraizou a atinge diretamente ou indiretamente em todas as suas partes, social, psicológica, física. O fator social é essencial. Não há verdadeiramente malheur onde não há, sob uma forma qualquer, degradação social ou apreensão de uma tal degradação ${ }^{39}$ (PSO, p. 62-63).
\end{abstract}

Por conseguinte, é oportuno ressaltar que o reconhecimento da presença do malheur por parte do sujeito é imprescindível para o seu estabelecimento, visto que é mediante esta atitude de reconhecimento que a consciência também é afetada. Em outras palavras, a alma ferida faz com que o sujeito sinta, em todas as suas faculdades,

\footnotetext{
${ }^{37}$ En revanche une douleur seulement physique est très peu de chose et ne laisse aucune trace dans l'âme.

38 Il en est autrement d'une souffrance physique très longue ou très fréquente. Mais une telle souffrance est souvent tout autre chose qu'une souffrance; c'est souvent un malheur.

39 Il n'y a vraiment malheur que si l'événement qui a saisi une vie et l'a déracinée l'atteint directement ou indirectement dans toutes ses parties, sociale, psychologique, physique. Le facteur social est essentiel. Il n'y a pas vraiment malheur la où il n'y a pas sous une forme quelconque déchéance sociale ou appréhension d'une telle déchéance.
} 
os efeitos dilacerantes do malheur, e isso atinge a totalidade da sua estrutura ontológica, ao passo em que:

\begin{abstract}
As três faces de nosso ser são sempre expostas. A nossa carne é frágil; não importa que pedaço de matéria em movimento possa trespassar, rasgar, esmagar ou deformar para sempre uma das suas engrenagens internas. A nossa alma é vulnerável, sujeita a depressões sem causa, lastimavelmente dependente de toda a espécie de coisas e de seres, eles próprios frágeis ou caprichosos. A nossa pessoa social, da qual quase depende o sentimento da nossa existência, é constante e integralmente exposta a todos os acasos. O próprio centro do nosso ser está ligado a essas três coisas por fibras tais que lhes sente todos os ferimentos um pouco graves ao ponto de sangrar ele mesmo. Sobretudo, tudo o que diminui ou destrói o nosso prestígio social, o nosso direito à consideração, parece alterar ou abolir a nossa própria essência, tanto temos por substância a ilusão ${ }^{40}$ (PSO, p. 77).
\end{abstract}

É pertinente destacar que, segundo Weil, existem diferenças gradativas entre os sujeitos no tocante ao limite a partir do qual o sofrimento pode ser considerado malheur, ainda que este limite exista para todo ser humano, não sendo, portanto, homogêneo o estágio no qual a experiência de sofrimento se converte no desenraizamento da vida, diante do que a autora esclarece em seus Cadernos:

[...] o malheur-limite, o malheur destruidor do eu é diferente segundo as pessoas; o limite se situa mais ou menos longe no malheur segundo o caráter, e mais quando mais longe ele está situado, mais dizemos que o caráter é forte. Mas esse limite, situado aqui ou lá, existe para todo ser humano, e se o acaso os leva até o ponto de malheur onde está situado seu limite, o eu neles entre no processo de destruição ${ }^{41}$ (OC VI 2, p. 463).

Em Espera de Deus, por sua vez, Weil reitera que um mesmo acontecimento pode ter a propriedade de precipitar um sujeito no estado de malheur, mas não outro.

\footnotetext{
${ }^{40}$ Les trois faces de notre être y sont toujours exposées. Notre chair est fragile; n'importe quel morceau de matière en mouvement peut la per-cer, la déchirer, l'écraser ou encore fausser pour toujours un des rouages intérieurs. Notre âme est vulnérable, sujette à des dépressions sans causes, pitoyablement dépendante de toutes sortes de choses et d'êtres eux-mêmes fragiles ou capricieux. Notre personne sociale, dont dépend presque le sentiment de notre existence, est constamment et en-tièrement exposée a tous les hasards. Le centre même de notre être est lié à ces trois choses par des fibres telles qu'il en sent toutes les blessu-res un peu graves jusqu'à saigner lui-même. Surtout tout ce qui diminue ou détruit notre prestige social, notre droit à la considération, semble altérer ou abolir notre essence elle-même, tant nous avons pour substance l'illusion.

${ }^{41}$ [...] le malheur-limite, le malheur destructeur du je est différent selon les gens; la limite se situe plus ou moins loin dans le malheur selon le caractère, et plus elle est située loin, plus on dit que le caractère est fort. Mais cette limite, située ici ou là, existe pour tout être humain, et si le hasard les porte jusqu'au point de malheur où est située leur limite, le je en eux entre dans le processus de destruction.
} 
Dito de outro modo, o limite a partir do qual se detecta a existência do malheur não é estabelecido de maneira objetiva, mas pressupõe critérios relativos à situação dos sujeitos, ainda que, vale recordar, exista para todo ser humano, visto que:

\begin{abstract}
Entre o malheur e todas as tristezas que, mesmo que sejam muito violentas, muito profundas, muito duráveis, são outra coisa que não o malheur propriamente dito, existe ao mesmo tempo continuidade e a separação de um limiar, como para a temperatura de ebulição da água. Há um limite além do qual se encontra o malheur e não abaixo. Este limite não é puramente objetivo; toda sorte de fatores pessoais entra na conta. Um mesmo evento pode precipitar um ser humano no malheur e não outro ${ }^{42}$ (PSO, p. 63).
\end{abstract}

É possível evidenciar explicitamente a articulação entre a dimensão especulativa e a dimensão concreta na filosofia weiliana, uma vez que as ressonâncias oriundas do contato com o império da força, aquela que converte os seres humanos em coisas dúcteis e manipuláveis, reconhecidas em termos da exploração do trabalhador e da guerra, são reiteradas e mesmo estendidas a outras instâncias em passagens como a seguinte:

\begin{abstract}
O grande enigma da vida humana não é o sofrimento, é o malheur. Não é de surpreender que inocentes sejam mortos, torturados, expulsos de seus países, reduzidos à miséria ou à escravidão, encerrados em campos ou em masmorras, desde que se encontram criminosos para cumprir essas ações. Nem é mais surpreendente que a doença imponha longos sofrimentos que paralisam a vida e a tornam uma imagem da morte, desde que a natureza está submissa a um jogo cego de necessidades mecânicas. [...] No melhor dos casos, aquele que o malheur marca não manterá senão metade de sua alma ${ }^{43}$ (PSO, p. 63).
\end{abstract}

Por conseguinte, o malheur, assimilado como uma pulverização da alma pela brutalidade das circunstâncias, implica num destroçamento irrevogável dela, dado que imprime-lhe marcas irremediáveis para além de um mero estado de alma, e a

\footnotetext{
${ }^{42}$ Entre le malheur et tous les chagrins qui, même s'ils sont très violents, très profonds, très durables, sont autre chose que le malheur proprement dit, il y a à la fois continuité et la séparation d'un seuil, comme pour la température d'ébullition de l'eau. Il y a une limite au-delà de laquelle se trouve le malheur et non en deçà. Cette limite n'est pas purement objective ; toutes sortes de facteurs personnels entrent dans le compte. Un même événement peut précipiter un être humain dans le malheur et non un autre.

${ }^{43}$ La grande énigme de la vie humaine, ce n'est pas la souffrance, c'est le malheur. II n'est pas étonnant que des innocents soient tués, torturés, chassés de leurs pays, réduits à la misère ou à l'esclavage, enfermés dans des camps ou dans des cachots, puisqu'il se trouve des criminels pour accomplir ces actions. II n'est pas étonnant non plus que la maladie impose de longues souffrances qui paralysent la vie et en font une image de la mort, puisque la nature est soumise à un jeu aveugle de nécessités mécaniques. [...] Dans le meilleur des cas, celui que marque le malheur ne gardera que la moitié de son âme.
} 
insignificância e degradação a ele associadas macula o ser humano em sua essência, conduzindo a uma passagem da personalidade ao anonimato insuscetível de ser expressada e aniquiladora da possibilidade de compaixão (MARTINS, 2013, p. 204205), haja vista que:

\begin{abstract}
Aqueles a quem chegou um desses golpes após os quais um ser se debate sobre o solo como um verme meio esmagado, aqueles não têm palavras para exprimir isso que lhes chega. Entre as pessoas que os reencontram, aqueles que, mesmo tendo muito sofrido, nunca tiveram contato com o malheur propriamente dito, não têm qualquer ideia do que ele é. É qualquer coisa específica, irredutível a qualquer outra coisa, como os sons, dos quais nada pode dar a ideia a um surdo-mudo. E aqueles que foram eles mesmos mutilados pelo malheur estão fora do estado de socorrer quem quer que seja, e quase mesmo incapazes de desejá-lo ${ }^{44}$ (PSO, p. 63).
\end{abstract}

No intuito de captar a essência semântica do termo malheur, Poulin (2010, p. 2) assevera que o seu alcance dramático atinge a imaginação e o afeto humano de maneira tão forte e incisiva que resiste, de início, a qualquer tentativa de caracterização clara e distinta, ao passo em que declara:

\footnotetext{
Textualmente, significa "tempo ruim" ou "destino ruim", e na língua francesa antiga foi escrito "infeliz", deixando aparecer em seu tom a ideia de um mal devastando repentinamente a existência de um ser, que se opõe brutalmente a seus sentimentos, contrariando seus desejos, provocando ou iniciando sua resistência. Embora o idioma dê-lhe muitos sinônimos - infortúnio, desgraça, aflição, desespero, etc. -, ele continua a ser o representante único de todos os sentidos usados pelas palavras que podem ser trocadas por ele. Exprime dor e sofrimento em suas manifestações mais poderosas, denotando um sofrimento indescritível ou a mais alienante das tragédias: é a criança morrendo no berço e a mãe que perde seu filho, é o paralítico que está esperando a morte na solidão e na família devastada pela violência da guerra [...] ${ }^{45}$ (POULIN, 2010, p. 2).
}

\footnotetext{
${ }^{44}$ Ceux à qui il est arrivé un de ces coups après lesquels un être se débat sur le sol comme un ver a moitié écrasé, ceux-là n'ont pas de mots pour exprimer ce qui leur arrive. Parmi les gens qu'ils rencontrent, ceux qui, même ayant beaucoup souffert, n'ont jamais eu contact avec le malheur proprement dit n'ont aucune idée de ce que c'est. C'est quelque chose de spécifique, irréductible à toute autre chose, comme les sons, dont rien ne peut donner aucune idée a un sourd-muet. Et ceux qui ont été eux-mêmes mutilés par le malheur sont hors d'état de porter secours à qui que ce soit et presque incapables même de le désirer.

${ }^{45}$ Textuellement, il signifie "mauvaise heure" ou "mauvaise destinée", et dans l'ancienne langue française il s'écrivait "malheurté", laissant poindre dans sa tonalité l'idée d'un mal terrassant soudain l'existence d'un être, s'opposant brutalement à ses sentiments, contrecarrant ses désirs, provoquant ou entamant sa résistance. Bien que la langue française lui alloue de nombreux synonymes infortune, disgrâce, affliction, désespoir, etc. --, il demeure l'unique représentant de l'ensemble des sens portés par les mots qui lui sont commutables. Il exprime la douleur et la souffrance dans leurs plus puissantes manifestations, désignant l'innommable détresse ou la plus aliénante des tragédies : c'est le nourrisson agonisant dans son berceau et la mère qui perd son enfant, c'est l'infirme qui attend la mort dans la solitude et la famille dévastée par les violences de la guerre [...].
} 
Sobrevém, por conseguinte, a dificuldade em encontrar uma resposta satisfatória para tal fenômeno que se apodera da existência humana, bem como para os seus pungentes efeitos, uma vez que qualquer tentativa de explicação plausível esbarra na resistência que o próprio termo impõe de ser definido, em termos do que emerge a indagação:

[...] como entender a base de um mal que, sem distinção, ataca tanto crianças como adultos, tanto os mais necessitados como os mais afortunados, tanto crentes como agnósticos? De todas as tradições e todas as culturas, o homem é assim interrogado sem jamais encontrar uma resposta lógica, a razão humana não permite ou não aceita nenhuma ${ }^{46}$ (POULIN, 2010, p. 2).

As reflexões da comentadora corroboram com a posição da filósofa segundo a qual o malheur está para além da dor meramente física, atingindo a totalidade da estrutura ontológica do ser humano, uma vez que:

[...] "mal-malheur", é nada menos que um desarraigamento da vida que neutraliza as aspiraç̃̃es eminentes de um ser humano, transmutando-os para um nebulosa e imagem penetrante da morte. "Mal-malheur" é "ao mesmo tempo dor física, angústia da alma e degradação social [...] ${ }^{47}$ (POULIN, 2010, p. 4).

Atestando a fragilidade humana, o malheur torna o sujeito opaco, distante, incompreensível e sem encontrar palavras para exprimir o que sente (VETÖ, 1997, p. 81). Verdade da condição humana enquanto desvela sua vulnerabilidade, o malheur é recepcionado das mais diversas maneiras por aqueles que acomete, visto que:

\begin{abstract}
Em numerosas situações, algumas pessoas respondem ao malheur com negação ou depreciação enquanto outros caem com prazer na "moda da sofrimento", dramatizando sua situação a favor do lucro ou da atenção particular: para aqueles a quem a vida favorece, a mentira consiste em negar o malheur dos outros ou inventar um para a ocasião, por pura vaidade. Para quem o malheur paralisa, a mentira consiste em negar o seu mal por causa do medo que a conscientização ou expressão produza um malheur ainda mais real e insuportável. Por outro lado, aquele que não está protegido
\end{abstract}

\footnotetext{
${ }^{46}$ [...] comment comprendre le fondement d'un mal qui, sans distinction, assaille les enfants comme les adultes, les plus nécessiteux comme les plus fortunés, les croyants comme les agnostiques? De toutes les traditions et de toutes les cultures, l'homme s'est ainsi interrogé sans jamais trouver de réponse logique, la raison humaine n'en permettant ou n'en acceptant aucune.

47 [...] "mal-malheur", n'est rien de moins qu'un déracinement de la vie qui neutralise les aspirations éminentes d'un être humain, les transmuant en une nébuleuse et pénétrante image de la mort. Le "mal-malheur" est "à la fois douleur physique, détresse de l'âme et dégradation sociale [...]".
} 
pela armadura de uma mentira não pode sofrer a força sem ser atingido até a alma ${ }^{48}$ (POULIN, 2010, p. 38).

Os efeitos pungentes do malheur atestam a possibilidade de que o malheureux seja destituído de todas as coisas que estão conectadas à existência, expressando-se, por conseguinte, numa angústia insuportável, sendo que:

\begin{abstract}
No malheur, quando a angústia se torna insuportável, derrama em lágrimas, linguagem universal de tristeza e única arma que os inocentes e os justos possuem para proteger a memória, a lembrança ou a essência daquilo que corre o risco de ser negligenciado, esmagado e perdido no malheur. Pelas lágrimas, o malheureux está relacionado à realidade da existência: aos seus olhos e aos olhos de todos, elas são uma prova de que ele ainda existe, mesmo que ele esteja despojado de todo o resto ${ }^{49}$ (POULIN, 2010, p. 46-47).
\end{abstract}

\title{
Considerações finais
}

Goethe nos recordou que, agir é fácil, pensar é difícil, adequar a ação ao pensamento é a coisa mais difícil. Hoje, numa época desenraizada é preciso retomar o que pensou e viveu Simone Weil na sua convicção de que o mal nasce em quem não mantém a capacidade de se alimentar de reflexão-ação. Por sua vez, Albert Camus, ao olhar para a herança da segunda guerra em 1949, alertou que seria impossível imaginar um renascer para a Europa que não tenha em conta as exigências definidas por Simone Weil. Simone Weil construiu uma filosofia sem precedentes. Embora alimentando-se dos pensadores do pasado, projetou uma particularidade filosófica singular.

\footnotetext{
${ }^{48}$ En de nombreuses situations, certains répondent au malheur par le déni ou la dépréciation alors que d'autres tombent avec plaisir dans "la mode de la souffrance", dramatisant leur situation au profit d'un bénéfice ou d'une attention particulière : pour ceux-là que la vie favorise, le mensonge consiste à nier le malheur des autres ou à s'en inventer un pour la circonstance, par pure vanité. Pour celui que le malheur paralyse, le mensonge consiste à démentir sa mauvaise fortune par peur que la conscientisation ou la mise en paroles ne rendent son malheur encore plus réel et insupportable. Par contre, celui qui n'est pas protégé par l'armure d'un mensonge ne peut souffrir la force sans en être atteint jusqu'à l'âme.

${ }^{49}$ Dans le malheur, quand l'angoisse devient elle aussi insupportable, elle s'épanche dans les larmes, langage universel de la tristesse et seule arme que les innocents et les justes possèdent pour protéger la mémoire, le souvenir ou l'essence de ce qui risque d'être négligé, écrasé et perdu dans le malheur. Par les larmes, le malheureux se rattache à la réalité de l'existence : à ses yeux et aux yeux de tous, elles sont la preuve qu'il existe encore, alors même qu'il est dépossédé de tout le reste.
} 
A filosofia que emerge de seus escritos não se dobra ao acadêmico modo de pensar. Quebrando padres, nos faz ver que mais do que um exercício de pensamento, a filosofia é uma resposta à vida. O chão emotivo é o pathos de seu pensamento: uma dis-posição que se configura fundamentalmente como uma tonalidade afetiva que nos harmoniza e nos convoca por um apelo, para além de uma mera sucessão de sentimentos incidentais, conforme nos recordou Martin Heidegger.

O modus operandi da filosofia de Simone Weil parte da particularidade do sofrimento como condição de possibilidade que desvenda a situação de opressão do homem. O sofrimento não é resultado de uma especulação racional feito pela autora, mas o sentir que emerge de sua inserção junto à vida dos trabalhadores ao perceber, por exemplo, a crueldade da cadência ininterrupta de movimentos repetitivos e, ao recordar que um dos seus efeitos consistia na redução do operário ao estado de inconsciência acerca de suas próprias ações, o que ocasionava aquilo que ela denomina “estado de besta de carga".

O sofrimento se torna mais compreensivo quando situado no horizonte dos imperativos da força, fato que Simone Weil se dispõe a analisar em sua apresentação mais horrível, a saber, a violência humana, causa desse processo de despersonalização infernal do homem. Nesse contexto, somos conduzidos à mais singular das realidades analisada por Weil, quando ela nos oportuniza a compreensão do sentimento do

malheur. É pertinente, portanto, reconhecer que a experiência weiliana do sofrimento se desmembra no malheur, definido por ela como um desenraizamento integral da vida humana, acometendo todas as faculdades do sujeito e concretizando o processo de despersonalização infernal implicado pela violência no contexto do império da força.

\section{Lista de abreviaturas das obras se Simone Weil}

OC Oeuvres complètes I, II, III... (Obras completas)

$\boldsymbol{A D}$ Attente de Dieu (Espera de Deus)

C Cahiers (Cadernos)

$\boldsymbol{C O}$ La condition ouvrière (A condição operária)

CS La connaissance surnaturelle ( $O$ conhecimento sobrenatural) 
$\boldsymbol{E} \quad$ L'Enracinement (O enraizamento)

$\boldsymbol{E H P}$ Écrits historiques et politiques (Escritos históricos e políticos)

$\boldsymbol{E L}$ Écrits de Londres et dernières lettres (Escritos de Londres e últimas cartas)

IPC Intuitions pré-chrétiennes (Intuições pré-cristãs)

$\boldsymbol{L P} \quad$ Leçons de philosophie (Aulas de filosofia)

$\boldsymbol{L} \boldsymbol{R} \quad$ Lettre à un religieux (Carta a um religioso)

OL Oppression et liberté (Opressão e liberdade)

$\boldsymbol{P} \quad$ Poèmes (Poemas)

PG La pesanteur et la grâce (A gravidade e a graça)

PSO Pensées sans ordre concernant l'amour de Dieu (Pensamentos sem ordem acerca do amor de Deus)
$\boldsymbol{S} \quad$ Sur la science (Sobre a ciência)
SG La source grecque (A fonte grega)

\section{Referencias}

ARISTÓTELES. Ética a Nicômaco. Trad. Leonel Vallandro e Gerd Bornheim. São Paulo: Abril, 1984.

BINGEMER, M. C. L. Simone Weil: a força e a fraqueza do amor. Rio de Janeiro: Ed. Rocco, 2007.

BINGEMER, M. C. L. Simone Weil: a vida em busca da verdade. Revista do Instituto Humanitas Unisinos, São Leopoldo, n. 313, nov. 2009a.

BINGEMER, M. C. L. Simone Weil: pioneira do diálogo inter-religioso. In: BINGEMER, M. C. L.(Org). Simone Weil e o encontro entre as culturas. Rio de Janeiro: Ed. PUC-Rio/Paulinas, 2009b. p. 235-263 p.

BINGEMER, M. C. L. Simone Weil: uma mística para o século XXI. In: TEIXEIRA, F. (org.) Caminhos da mística. São Paulo: Paulinas, 2012. p. 135-164.

BINGEMER, M. C. L. Violência e não-violência: força e sofrimento no pensamento de Simone Weil. In: BINGEMER, M. C. L.; DI NICOLA, G. P. (Orgs). Simone Weil: ação e contemplação. Bauru: Ed. Edusc, 2005. 129-151 p.

BORDIN, L. Simone Weil: da experiência do trágico a uma ética do limite e da responsabilidade. Revista sintese nova fase, Belo Horizonte, v. 23, n. 75, p. 525-536, 1996. 
BOSI, A. Simone Weil: a inteligência libertadora e suas formas. In: BINGEMER, M. C. L. (Org). Simone Weil e o encontro entre as culturas. Rio de Janeiro: Ed. PUC-Rio/Paulinas, 2009. 13-37 p.

BOSI, E. Simone Weil. BOSI, E. (Org). A condição operária e outros estudos sobre a opressão. Trad. Therezinha Gomes Garcia Langlada. Rio de Janeiro: Ed. Paz e Terra, 1996. p. 21-81.

COLES, R. Simone Weil: a modern pilgrimage. Woodstock: Ed. SkyLight Paths, 2009. p. 26892694.

DI NICOLA, G. P.; DANESE, A. A busca da verdade pautada pela mística. Revista do Instituto Humanitas Unisinos, São Leopoldo, n. 313, nov. 2009.

DI NICOLA, G. P. A universalidade de Simone Weil na questão do batismo. In: BINGEMER, M. C. L. (Org). Simone Weil e o encontro entre as culturas. Rio de Janeiro: Ed. PUCRio/ Paulinas, 2009. p. 171-205.

ESTELRICH, B. Filosofia como exercício espiritual: Simone Weil e Pierre Hadot. In: BINGEMER, M. C. L. (Org). Simone Weil e o encontro entre as culturas. Rio de Janeiro: Ed. PUCRio/Paulinas, 2009a. p. 39-57.

ESTELRICH, B. Filosofia weiliana: um processo de contemplação. Revista do Instituto Humanitas Unisinos, São Leopoldo, n. 313, nov. 2009b.

GABELLIERI, E. Enraizamento e encarnação: dimensões do diálogo intercultural e interreligioso em Simone Weil. In: BINGEMER, M. C. L. (Org). Simone Weil e o encontro entre as culturas. Rio de Janeiro: Ed. PUC-Rio/Paulinas, 2009. p. 107-126.

GABELLIERI, E. Simone Weil. Paris: Ed. Ellipses, 2001.

GABELLIERI, E. Simone Weil: uma filosofia da mediação e do dom. In: BINGEMER, M. C. L.; DI NICOLA, G. P. (Orgs). Simone Weil: ação e contemplação. Bauru: Ed. Edusc, 2005. p. 213-214.

GARCÍA, E. A. Percepción y lectura en la filosofía de Simone Weil. Buenos Aires: Ed. Teseopress, 2015.

GUIMARÃES, M. A. A metáfora do hóspede: a experiência mística e a recriação do "si mesmo". In: BINGEMER, M. C. L. (Org). Simone Weil e o encontro entre as culturas. Rio de Janeiro: Ed. PUC-Rio/Paulinas, 2009. p. 321-325.

GUIMARÃES, M. A. Perfil de Simone Weil. In: BINGEMER, M. C.; DI NICOLA, G. P. (org.) Simone Weil: ação e contemplação. Bauru: Edusc, 2005. p. 17-48.

HEIDEGGER, M. O que é a filosofia. In: HEIDEGGER, M. Conferências e escritos filosóficos. Trad. Ernildo Stein. São Paulo: Ed. Nova Cultural, 1999.

JUliANO, M. A. G. Um perfil de Simone Weil. Revista do Instituto Humanitas Unisinos, São Leopoldo, n. 313, nov. 2009.

MACALUSO, S. Il metaxy: la filosofia di Simone Weil. Roma: Ed. Armando, 2003. 
MARTINS, A. A. A pobreza e a graça: experiência de Deus em meio ao sofrimento em Simone Weil. São Paulo: Ed. Paulus, 2013. p. 25-35.76-77.

MORAES, A. S. A pedagogia da experiência humana: Aquiles e o sofrimento que ensina. Phoînix, Rio de Janeiro, p. 11-26, 2015. Disponível em: $<$ http://phoinix.historia.ufrj.br/media/uploads/artigos/A_PEDAGOGIA_DA_EXPERI ENCIA_HUMANA_-_Alexandre_Moraes.pdf>. Acesso em: 22 fev. 2018.

PÉREZ, E. B. Simone Weil: esperar na ausência de esperança. In: BINGEMER, M. C. L. (Org). Simone Weil e o encontro entre as culturas. Rio de Janeiro: Ed. PUC-Rio/Paulinas, 2009. p. 73-92.

PÉTREMENT, S. Vida de Simone Weil. Madrid: 1997.

POULIN, M.-亡̀. Le sacrement du malheur chez Simone Weil. Montreal: Université de Montreal, 2010.

PUENTE, F. R. A matemática como metaxu entre a Grécia e o cristianismo. In: BINGEMER, M. C. L. (Org). Simone Weil e o encontro entre as culturas. Rio de Janeiro: Ed. PUCRio/Paulinas, 2009. p. 147-158.

VETÖ, M. La métaphysique religieuse de Simone Weil. Paris: Ed. L'Harmattan, 1997.

WEIL, S. A fonte grega. In: BOSI, E. (Org). A condição operária e outros estudos sobre a opressão. Trad. Therezinha Gomes Garcia Langlada, Rio de Janeiro, Ed. Paz e Terra, 1996.

WEIL, S. A gravidade e a graça. Trad. Paulo Neves. São Paulo: Ed. Martins Fontes, 1993.

WEIL, S. Attente de Dieu. Paris: Ed. Gallimard, 1966.

WEIL, S. Essay on the concept of reading. In: SPRINGSTED, E. (Org.). Simone Weil: late philosophical writings, Indiana, Ed. University of Notre Dame Press, 2015.

WEIL, S. Intuitions pré-chrétiennes. La Colombe: Ed. Vieux Colombier, 1951.

WEIL, S. La condition ouvrière. Paris: Ed. Gallimard, 1951.

WEIL, S. La connaissance surnaturelle. Paris: Ed. Gallimard, 1950.

WEIL, S. La pesanteur et la grâce. Paris: Ed. Plon, 1947.

WEIL, S. Leçons de philosophie: Roanne 1933-1934. Paris: Ed. Union Générale d’Éditions, 1959. p. 94-98.244.

WEIL, S. L'enracinement: prélude à une déclaration des devoirs envers l'être humain. Paris: Ed. Gallimard, 1949.

WEIL, S. Lettre à un religieux. Paris: Ed. Gallimard, 1951.

WEIL, S. Oeuvres complètes: tome I: premièrs écrits philosophiques. Paris: Ed. Gallimard, 1988.

WEIL, S. Oeuvres complètes: tome VI: cahiers 1. Paris: Ed. Gallimard, 1994.

WEIL, S. Oeuvres complètes: tome VI: cahiers 2. Paris: Ed. Gallimard, 1997. 
WEIL, S. Oppression et liberté. Paris: Ed. Gallimard, 1955.

WEIL, S. Pensées sans ordre concernant l'amour de Dieu. Paris: Ed. Gallimard, 1962.

WEIL, S. Philosophy. In: SPRINGSTED, E. (Org.). Simone Weil: late philosophical writings. Indiana: Ed. University of Notre Dame Press, 2015.

WEIL, S. Some reflections on the concept of value. In: SPRINGSTED, E. (Org.). Simone Weil: late philosophical writings. Indiana: Ed. University of Notre Dame Press, 2015.

WEIL, S. Sur la science. Paris: Ed. Gallimard, 1966. p. 59-60. 